\title{
Sisters and SaVAges: Putting the VA in th e Acti.VA.tion
}

Slide 1: Aolele, Pacific Sisters He Toa Tāera- Fashion Activists opening, Acti.VAtion, Te Papa Tongarewa, Wellington, NZ. Image: Kerry Brown, 2018.

Slide 2: Peka, Breathing in Glass, Running Out of Breath, Engine Room, Massey University, Wellington, NZ. Image: Kerry Brown, 2017.

I cry the ocean

I bleed the earth

I sleep with mountains

I greet you with my dead

May my waters greet your waters May my mountains greet your mountains May my house greet your house May my people greet your people

Let us take a moment to acknowledge those who have passed, for we are the past, we are the present, we are the future.

Greetings and acknowledgments to Ngāti Whātua who hold the mana of Tamaki Ma kau rau, where we gather today.

Thanks and praise to our hosts University of Auckland, AUT, Ngā Pae o te Māramatanga, and special mention to the Ka Haka organisers for the invitation to talk story with you all.

Before bird catching a little offering must be made, so it is here I must acknowledge my tipuna...of the past and in the present and take time to thank some of the peoples who have helped shape my artistic and cultural journey ...... The Pacific Sisters, Albert Refiti, Albert Wendt, Okusi Mahina, Ole Maiava, Amiria 
and Anne Salmond, Billie Lythberg, The SaVAge K'lub and the Urban Moana Oceania creative community who continues to nurture me.

Slide 3: Malie I Uta (Shark of the Land), Blak Dot Gallery, Melbourne, Australia. Collaborative Image: Jermaine Dean. Body Make up: Jocelyn Ng, 2017.

The Smell of the Sea

Guess who is coming to dinner

A full-bodied blossom ensemble

A heady mix of ylang-ylang, sandalwood and the smell of the sea

No need to pay and display, this will be all you can eat

I've got a banana walk with pukeko legs, when I run my feathers ruffle, when they drop, new islands form

Unfolding, Evolving, Unfeigned, Veracity, Capacity, Fluency, Remedy, Materiality, Clarity

I weave with words not fibers,

I paint with shadows not colours

I am the wind, soft, flowing over boulders, they are large and round sitting by the water

I wish I was a shark or maybe it's just that I remember when I was one...makes me predator proof..... hmmm show me your teeth and I'll show you my growler

I didn't look into your eyes, I know they the same colour as the bottom of the ocean, dark but full of life...mine are all white and shaped like an ocean going vessel they have purerehua inside them so you can hear me coming

I can be quiet but have trouble standing still, I vibrate, feel me in the back of your throat, I'm going for your heart, so keep 
your mouth closed unless you want it to be taken, it won't be forced but it will be slow

The old city talks to me, the old river confuses me as it endeavors to enter me

Luckily I have a tight sphincter and sit with my legs crossed

My hunger replaced by man-made thunder

Come dine on me, my flesh is sweet no need for marinating, just truss me up like a long pig, wrap me in banana leaves

Devour me, all that will be left will be the smell of the sea.

Slide 4: Beaten, Twisted, Flowing, 10th Festival of the Pacific Arts, Pago Pago, American Samoa. Image: Kerry Brown, 2008.

Haroro, my name is Rosanna Raymond aka Sistar S'pacific

Slide 5 a+b: Pacific Sisters detail Eyeland Part 2-Welkome 2 da K'lub, Pasifika Styles, Cambridge University of Archaeology and Anthropology, UK. Image: Rosanna Raymond 2006.

Long-time member of the Pacific Sisters

Slide 6: Ani O'Neill Opening Weekend SaVAge K'lub, 8th Asia Pacific Triennal, GOMA, Brisbane, Australia, 2015.

Self-appointed life time President and founding member of the SaVAge K'lub.

I am a Culti.VA.tor, FAB.ricator and Acti.VA.tor of spaces, people and things.

This is a choreographic process that extends beyond the frames of art, into both domestic routines and ritual protocols. It includes self-adornment and group enactments, activating space and collapsing time using the body and the genealogical matter.

I am a maker 
Slide 7: Fabricating, Indigeneity in the Contemporary World Project, Dahlem Museum, Berlin, Germany. Image: Taille Renouf, 2014.

A visual artist

Slide 8: Is That a Tusk In Your Mouth Or You Just Pleased To See Me, Dead Pigs Don't Grow On Trees, Mangere Arts Centre. Image: Kerry Brown, 2014.

A scribe

Slide 9: An EYEland Adventure.

Using the body as the main material to activate the mauli of my creations.

Slide 10 a+b: I Malie I Tanifa, Acti.VA.tion,Toi Tū, Auckland, NZ. Image: Jaimie Waititi, 2016

The foundation of my art practice started in the 90's with the arts collective the Pacific Sisters. With the Pacific Sisters I learnt how to use my hands as a maker, fusing traditional techniques, oral histories, genealogies from the Pacific alongside modern materials and stories to create... in fact demand a presence in the urban landscape of Aotearoa as a NZ born Pacific Islander of Samoan decent. The Pacific Sisters allowed me to manifest a space where my ancient and my modern self could embrace and engage with each other. We were not interested in replicating the past but creating a space where we could add to the dynamic legacy of our cultural heritage...we were largely ignored by the art world and our own communities.

Earlier this year saw the opening of Pacific Sisters- He Toa Tāroa Fashion Activists at the Museum of New Zealand Te Papatongarewa celebrating over 25 years of sisterhood... coming to a gallery near you, opening at the Auckland City Art Gallery next year in February.

Slide 11: Pacific Sisters Toi Art Gallery Opening -ActiVAtion Te Papa Museum 2018. Video by Pākē Salmon. (https://www.youtube.com/watch?v=xOVQcxxneD4) 
Slide 12: MamaTane TuKu Ia, Acti.VA.tion, Silo Park, Auckland, NZ. Courtesy Te Tuhi. Image: Pake Salmon, 2018

My body, its language and the language of the mea (things) I adorn it with has become a powerful space for my art practice and cultural heritage to come together, the past and the present converging in the NOW. My body has become a site of resistance, allowing me to traverse the genealogical and geographical space, collapsing time, helping to re-render and privilege my Moana body.

I do this by centralizing the Samoan Indigenous index of the Vā as an embodied practice. Vā, a Samoan term for space. This space is not a linear space, or indeed an empty one. The $V \bar{a}$ is an active space. It is activated by people. It binds people and things together. It forms relationships and necessitates reciprocal obligations.

Historically Samoan cultural understandings of the Vā have been grounded in relational and social space within a village setting in Samoa. The notion of the vā is changing as it spreads throughout our transnational communities. This new geographical vā/space begets new narratives and experiences creating new Moana Oceania thought and ways of being. The work of Wendt, Refiti, Mahina, Mila, Tavita pioneers of the tā/vā theory over the past 10 years have hugely influenced my creative practice. I am only just starting to articulate my thoughts more formally.

So while the emphasis is often placed on the relational and social space how it is formed and maintained, rarely is the body's presence as a vessel for the past, present, future and how it activates the mauli (the spark of life) brought into the Tâ-Vā theory. I want to look at how to centralise indigenous ways of being and knowing though the body. How can the living performative body expand the concept of the Tā-Vā theory?

It was Albert Refiti who framed the "nesian body as the genealogical matter of the ancestor... the body the architecture of the ancestor...this changed my thinking to what it was I actually doing in the performative realm - whether artistically or culturally.

With the Pacific Sisters I was exploring personifying the atua (god), as I developed my thinking and practice I realized I was in fact sharing space with the atua, my genealogical past, my body becomes the site where I am able to collapse time and 
space and present the past in the now... the body and all that adorns it become a time capsule...a space ship.. a Vaka...we travel together.

This is what I call putting the VA in the acti.VA.tion. It is an immediate exchange, both real time and one that is perpetuated outside the physical time and space... through the memory of the shared experience.

Slide 13: Acti.VA.tion: Using the cultural index of the vā as a methodology to bring the past into the present through an embodied practice.

I use the Va as an embodied methodology... using spoken words, through performative based works, through the practice of making and adorning people and things with special attention in regards to re-activating cultural belongings in museums...the space created when we connect allows the time/space to collapse...they live through us and we through them at the point of contact. Allowing the museum space to be an active space of convergence not just a place where people and things are framed in the past.

Like tāonga (cultural treasures) without their kōrero (narrative), without their intangible histories, my images, body adornments can be easily experienced as objects, only one part of a whole. My fabrications await the body to acti.VA.te the mauli (the spark of life), something tangible happens. Felt rather than seen, a visceral experience. These are not performances, they are performative yes, theatrical...yes... but the stage and audience come in many guises.

Slide 14a: SaVAge Niwhai Tupaea, Inaugural SaVAge K'lub Meeting Brisbane, $8^{\text {th }}$ Asia Pacific Triennale, GOMA, Brisbane, Australia. Image: J Ruckli.

Slide 14b: SaVAge Tai Paitai, Inaugural SaVAge K'lub Meeting Auckland, Acti.VA.tion, Toi Tū, Auckland. Image: Salvador Brown, 2014.

This brings me to the SaVAge K'lub, we put the vā into the SaVAge. Founded in 2010 by my own self. The SaVAge K'lub presents 21 st Century South Sea savagery, influencing art and culture through the interfacing of time and space, deploying weavers of words, rare anecdotalists, myth makers, 
hip shakers, navigators, FAB.ricators, Acti.VAtors, to culti.VA.te the non cannibalistic cognitive consumption of the other.

The SaVAge K'lub come together to celebrate all forms of art and culture, collaborating to acti.VA.te people and things. They have participated in large-scale art projects in Australia, Aotearoa NZ and have held workshops in New York, Olympia, Rarotonga and London, lending their charm and regalia for consensual SaVAging all over the globe.

Like a mat woven, our bodies weave together geographical and genealogical strands, part body part art, expanding the concept of $v \bar{a}$, by creating temporal and spatial connections, to (re)tell our stories, (re)claiming our bodies, (re)privileging the indigenous selves through the arts and having a whole pile of fun at the same time... and space.

Faafetai ma le fa'afetai

Slide 15: Malie I tai (Shark of the Sea), Blak Dot Gallery, Melbourne, Australia. Collaborative Image: Jermaine Dean. Body Make up: Jocelyn Ng, 2017.

Sistar S'pacific aka Rosanna Raymond is an innovator of the contemporary Pasifika art scene as a long-standing member of the art collective the Pacific Sisters and founding member of the SaVAge K'lub. Raymond has achieved international renown for her performances, installations, body adornment, and spoken word. A published writer and poet, her works are held by museums and private collectors throughout the UK, USA, Canada, Australia and New Zealand. 